Hamburger died at Groningen on January 4, 1924, aged sixty-five.

\section{Peaceful Uses of Outer Space}

Mr. R. Altuan, Under-Secretary of State for Foreign Affairs, stated in a written answer in the House of Commons on February 24 that last December the General Assembly of the United Nations set up an ad hoc Committee to study the question of international co-operation in the peaceful uses of outer space under United Nations auspices. The Committee, which is composed of eighteen member States, including the United Kingdom, the United States of America and the Soviet Union, is to consider the co-ordination of national research programmes. So far, the Soviet, Polish and Czechoslovak delegates have refused to participate in the work of this Committee, but Mr. Allan hoped that they will reconsider their decision.

\section{Research on Road Accidents}

Is a written reply to a question in the House of Commons on February 25 as to the steps being taken to increase research on the prevention of road accidents, Mr. H. Nicholls, Parliamentary Secretary to the Ministry of Works, representing the Lord President of the Council, said that extensive researches with this objective generally were being carried out by the Road Research Laboratory. This covered such problems as the control of vehicles during emergency braking, improvements in tyres and road surfaces to give better adhesion on wet roads, improvements in vehicle and street lighting, and in helmets for motorcyclists. Safety aspects of motor-vehicle design to minimize injuries in road accidents were being investigated in the Slough area in co-operation with the police and the Medical Research Council. The staff available for this detailed study had recently been increased, and facilities for simulating accidents and testing individual components were being built up. Full co-operation existed, and the Laboratory studied research results obtained in the United States and elsewhere with a view of their application here. In 15 per cent of accidents studied in 1955-58 a mechanical defect in the vehicles had played an important part and about half the defects were in the brakes.

\section{Chapelcross Nuclear Power Station}

Ax the United Kingdom Atomie Energy Authority's nuclear power station at Chapelcross, near Annan, Dumfriesshire, the first of the four reactors, which became critical last November, has now been taken in service for the generation of electricity. The Chapelcross station, which will have a generating capacity of $184,000 \mathrm{~kW}$. and will, when all four reactors are completed, feed about $140,000 \mathrm{~kW}$. to the national grid, has been built by the United Kingdom Atomic Energy Authority as a dual-purpose station to provide plutonium and electricity. Another nuclear power station is being built by the South of Scotland Electrieity Board at Hunterston in Ayrshire for the provision of electricity and will supply $320,000 \mathrm{~kW}$. of power to the grid. The construction of Chapelcross is under the control of Messrs. Merz and McLellan, acting as agents for the Atomic Energy Authority's Industrial Group; this is the first occasion on which a private firm has been employed in this way in Britain on a major project. The official opening of the Chapelcross Station, by Sir
John Crabbe, Lord Lieutenant of Dumfriesshire, will be on May 2, when it will be open to the public.

\section{New Oceanographical Ship for Woods Hole}

THE sea-going fleet of the Woods Hole Oceanographic Institution, Massachusetts, was recently increased to five ships by the addition of the $92-\mathrm{ft}$. auxiliary ketch Aries, to do scientific work around Bermuda under Dr. John Swallow. Purchase of the ship was made possible with funds made available for the purpose by Mr. Richard J. Reynolds, of Sapelo Island, Georgia. Aries will be used mostly to study sub-surface ocean currents with the aid of Dr. Swallow's neutrally buoyant floats, which were used last year in the discovery of a counter-current under the Gulf Stream and in studying the outflow of Mediterranean water through the Straits of Gibraltar in the co-operative effort of the British National Institute of Oceanography and the Woods Hole Oceanographic Institution during the recent International Geophysical Year.

Built in 1953 of teakwood over steel frames, at the Camper and Nicholson Yard in Gosport, Aries was designed for world-wide cruising and is well appointed. Aft there is generous room for nine, and her forecastle has room for six. The ship is $70 \mathrm{ft}$. long on the water line, and has a beam of $19 \frac{1}{2} \mathrm{ft}$. and a draught of $12 \mathrm{ft}$. Aries is equipped with a 100-h.p. AEC Diesel engine capable of driving the ship at 8 knots and has a fuel capacity for 2,000 miles. Built to Lloyd's highest specifications, the vessel has copper sheathing on the bottom. The ship will remain under the command of her captain, John W. Gates; the Woods Hole Oceanographic Institution will operate her with a crew of eight. The fleet of the Woods Hole Oceanographic Institution also includes the $213-\mathrm{ft}$. Chain, the 142-ft. Atlantis, the $125-\mathrm{ft}$. Crawford and the 110-ft. Bear. Two small vessels, Asterias and Risk, are used for inshore work.

\section{College Biology Courses on Television}

THE Fund for Advancement of Education established by the Ford Foundation has awarded Station $K E T C-T V$ and Saint Louis University a grant of 58,300 dollars to cover the academic costs for the production of a film series entitled "Principles of Genetics". The series of forty-five films, to be financed by the MeGraw-Hill Co. of New York, are scheduled to be shown over KETC-TV network initially in the spring semester of 1960 and will serve as the basis for a regular college credit course in genetics. Simultaneous with the initial showing in Saint Louis, the films will be available to all colleges, universities, hospitals and industries throughout the world. Prof. John D. Dwyer, director of the Department of Biology, and Dr. Irwin H. Herskowitz, associate professor of biology in Saint Louis University, will serve as special consultants in the organization of scientific data for the series of films. The subject-matter will be recorded on film by leading specialists in the field of heredity, and is the first television series in biology, given by a number of leading scientists, of the Educational Television Station's plan for a College of the Air.

\section{Brachiosaurus Exhibit at the Smithsonian Institution}

THE Smithsonian Institution has recently placed on exhibit in the Dinosaur Hall of its Natural History Building at Washington one of the largest dinosaur 